\title{
Rules governing the share capital of German public companies
}

\author{
by Frank Wooldridge
}

$\mathrm{T}$ The above rules are somewhat detailed and sometimes rather complex. A good elementary account of them by Schneider and Heidenhain is given in The German Stock Corporation Act ( 2nd ed, pub Kluwer, 2000) which has been of considerable interest and help to the author of this article.

The articles of a public company (Aktiengesellschaft) are required to specify the amount of the company's share capital, which has to be denominated in euros. The minimum capital of a public company is at present $€ 50,000$ (para $7 A k t G$ ). As in the United Kingdom, shares may be issued without a par value (Stückaktien) or with one (Nennbetragsaktien) (para 8(2) AktG). Par value shares are required to have the value of one euro or a multiple thereof (para 8(2) $A k t G$ ). The shares in an Aktiengesellschaft are indivisible, as are the rights attaching to each share.

The articles of an $A k t G$ are required by paragraph 23(1) $A k t G$ to take the form of a notarial deed. In the case of no par value shares the deed is required to state their number and issue price. In the case of par value shares, the deed is required to specify their par value. In addition, the deed must state the paid up amount of the share capital (para 23(2) No $3 \mathrm{AktG}$ ) and the subdivision of the shares into classes if more than one class exists, and the number of shares in each class (para 23(3) No $4 A k t G$ ).

According to paragraph 9(1) $A k t G$, shares must not be issued at a price lower than par value, or the par value attributable to each no par value share. Paragraph 9(2) $A k t G$ makes it clear that shares may be issued at a price higher than par value. As in most other jurisdictions, German law recognises that public companies may issue shares which confer special rights, in particular in relation to the distribution of profits, and the company's assets (para $11 A k t G$ ). Preference shares carrying no voting rights may be issued by a public company, according to paragraph $12 A k t G$. However, paragraph 12(1) AktG provides that otherwise each share shall carry equal voting rights.

Unlike English law, German law does not permit the use of multiple voting rights in respect of shares in a public company. However, it contains detailed rules governing the maintenance of capital. Certain of these rules, including the prohibition imposed on a public company subscribing for its own shares contained in paragraph 56(1) $A k t G$ are considered below. The imposition of ancillary obligations upon shareholders is also considered below, where the rules governing the increase and reduction of capital, which are rather complex, are dealt with in outline.

\section{THE PROVISIONS OF PARAGRAPH 56 AKTG}

The most important of the abov e provisions would seem to be those contained in paragraph 56(1) and 562) $A k t G$. Paragraph 56(1) $A k t G$ provides that a company may not subscribe for its own shares. Any purported subscription of such shares is treated as a nullity. Paragraph 56(2) $A k t G$ provides that a controlled undertaking (Abhängiges Unternehmen) may not acquire shares in the controlling undertaking (der herrschenden Gesellschaft) and that a subsidiary (ein in Mehrbesitz stehendes Unternehmen) may not acquire share in its parent company, either as a founder or subscriber, or by means of the exercise of conversion or pre-emptive rights granted in connection with a contingent capital increase.

Paragraph 56(2) $A k t G$ also stipulates that a violation thereof shall not invalidate each acquisition. A contingent capital increase is defined in paragraph 192(1) $A k t G$ as an increase of share capital which shall be carried out only to the extent that conversion rights or share warrants which oblige the company to issue new shares are exercised.

The provisions of paragraph 56(3) $A k t G$ are somewhat complex, and appear to be of a rather stringent character. This text provides that any person who acquires a share, whether as a founder or subscriber, or by exercising a conversion or pre-emptive right in connection with a contingent capital increase, on behalf of the company or an undertaking under its control, or a subsidiary thereof, shall not be exempt from liability on the ground that he did not acquire the shares on behalf of himself. He shall be liable for the full contribution irrespective of the terms of any 
agreement with the company, or the controlled undertaking, or the subsidiary. For so long as a person has not acquired the share on behalf of himself, he is not entitled to exercise any rights derived from it. A contingent increase of capital, which has been mentioned earlier in the preceding paragraph is, according to paragraph 192(1) $A k t G$ one which is carried out only to the extent that conversion rights or share warrants which require the company to issue new shares are exercised.

Paragraph 56(4) $A k t G$ is intended to implement the requirements of Article 28 of the Second Company Law Directive. It provides that if, in the event of an increase of capital, shares are subscribed for in violation of paragraph 56(1) or (2) $A k t G$, any member of the management board shall be liable to the company for the entire contribution. However, this rule is not applicable if a member of the management board shows that he is not at fault.

\section{THE PROHIBITION OF THE REPAYMENT OF CAPITAL, AND INTEREST ON CONTRIBUTIONS}

The above prohibition is contained in paragraph 57(1) $A k t G$, which stipulates that contributions may not be returned to shareholders. The payment of the purchase price in the event of a permissible acquisition of the company's shares is not treated as a repayment of contributions. Furthermore, the rule contained in the first sentence of this paragraph does not apply to payments (Leistungen) which take place on the basis of a control or profit transfer contract, or which are covered by a fully valid counterclaim or claim to be indemnified against shareholders. The rule contained in paragraph 57(1) AktG is also inapplicable to the return of a loan from shareholders, and payments in respect of claims arising from transactions which correspond with loans.

According to paragraph 57(2) $A k t G$, interest may be neither promised nor paid to shareholders. Furthermore, according to paragraph 57(3) $A k t G$, prior to the liquidation of the company, only distributionable profits may be paid to shareholders.

\section{THE ACQUISITION BY A COMPANY OF ITS OWN SHARES}

According to paragraph 71(1) $A k t G$, a public company may acquire its own shares in eight clearly defined circumstances. These are: (1) to prevent severe and imminent damage to the company; (2) for the purpose of offering shares to employees; (3) to compensate minority shareholders when entering into a control contract (Beherrschungsvertrag) or a profit transfer contract (Gewinnabfuhrungsvertrag) carrying out integration;

where shares are acquired without consideration being given or by a bank when dealing with a purchase order; (5) as a successor in title by operation of law; (6) on the basis of a resolution of the shareholders meeting to redeem shares according to the provisions applicable to a reduction of capital; (7) where the company is a credit or financial services institution, for the purpose of trading in securities on the basis of a resolution of its shareholders' meeting; (8) on the basis of a resolution of the shareholders' meeting giving authority to the company to purchase its own shares for a period of not more than five years. The latter resolution must fix the lowest and highest prices for the shares, and the percentage of share capital involved, which may not exceed 10 per cent.

Paragraph 71(2) AktG contains further provisions governing the acquisition by the company of its own shares. It stipulates that the shares acquired for the purposes specified in paragraph 71(1), nos 1, 2, 3, 7 and 8 $A k t G$, together with other company shares which the company has already acquired and continues to hold, must not exceed 10 per cent of the share capital. It also provides that such acquisition shall only be permitted if the company is then in a position to create a reserve amounting to the expenditure on the acquisition without reducing its capital or its reserves required by law or the articles, which may not be used to make payments to shareholders.

Paragraph $71 \mathrm{a}(1) \quad A k t G$ contains rules governing transactions providing for the grant of an advance or loan or the provision of security by the company to another person for the purpose of acquiring shares in the company. According to the first sentence of this provision, such transactions are null and void. However, it is clear from the following sentence that subject to a proviso this rule does not apply to transactions in the ordinary course of the business of credit or financial institutions, nor to the grant of advance or loan or the provision of security for the purpose of the purchase of shares in the company by employees of the company. Paragraph 71a(2) $A k t G$ stipulates that any transaction between the company and another person which obliges such a person to acquire shares in the company or one of its subsidiaries is null and void if the acquisition of the shares by the company itself would constitute a violation of paragraph 71(1) or (2) $A k t G$.

By paragraph $71 \mathrm{~b} A k t G$ the company has no rights in respect of its own shares which it holds. Paragraph 71c(1) $A k t G$ provides that if a company has acquired its own shares in violation of paragraph 71(1) or (2) $A k t G$, such shares must be sold within one year of the date of the acquisition. Paragraph $71 \mathrm{c}(2)$ provides that if the shares in the company which the company itself has lawfully acquired in accordance with paragraph 71(1) $A k t G$ and still holds exceeds more than one tenth of the share capital, the shares in excess of this percentage must be sold within three years of their acquisition. If the shares in the company which the company holds have not been sold within the periods prescribed by paragraph $71 \mathrm{c}(1)$ or (2) Aktg, paragraph $71 \mathrm{c}(3)$ provides that they shall be redeemed in accordance with paragraph $237 \mathrm{Akt} G$, which is concerned with the mandatory redemption of shares. 


\section{ACQUISITIONS BY THIRD PARTIES}

Paragraph 71d $A k t G$ is concerned with acquisitions by third parties of company shares held by the company. It provides that a third party acting in its own name but on behalf of the company may only acquire or hold shares in the company if the company would be permitted to make such an acquisition in accordance with paragraphs 71(1) nos 1-5, 7 and 8, and 71(2) $A k t G$.

\section{PLEDGE OF COMPANY'S SHARES HELD BY THE COMPANY}

Paragraph $71 \mathrm{e}(1)$ treats such a transaction as equivalent to an acquisition by the company of its own shares. It adds that a credit institution or financial services institution may, however, in the ordinary course of business take a pledge of company shares for an amount not exceeding the percentage of the share capital specified in paragraph 71(2) $A k t G$ : this is 10 per cent of the share capital.

\section{ANCILLARY OBLIGATIONS}

According to paragraph 55(1) $A k t G$, ancillary obligations (Nebenverflichtungen) may be imposed on a shareholder if the transfer of a share requires the consent of the company. By paragraph 55(2) $A k t G$, the articles of the company may provide for the imposition of penalties if such obligations have not been carried out, or carried out properly. It follows from paragraph 180(1) $A k t G$ that the imposition of ancillary obligations on shareholders by means of a company resolution requires the affirmative vote of all the shareholders concerned. According to paragraph $61 \mathrm{Akt}$, the company must pay compensation not exceeding the value of services given by shareholders in respect of recurring obligations which they are required to perform in addition to contributing to the share capital, irrespective of whether a distributable profit is shown in the balance sheet.

\section{THE NEED TO MAKE RESTITUTION}

By paragraph 62(1) $A k t G$ shareholders who receive benefits (including dividends) to which they know, or ought to have known, they were not entitled, must make restitution to the company. If such benefits consist of dividends, the shareholders are only bound to make restitution if they know, or as the result of their negligence did not know, that they were not entitled to them.

\section{SANCTIONS FOR THE NON-PAYMENT OF CONTRIBUTIONS}

According to paragraph 63(1) $A k t G$, shareholders are required to pay contributions on being called on to do so by the management board. If they fail to pay the amount called for within the required period of time they may, according to paragraph 63(2) $A k t G$, be required to pay interest at the rate of five per cent on the relevant amount from the date due. By paragraph 63(3) $A k t G$ the company's articles may impose penalties for late payment. In addition, paragraph $64 \mathrm{Akt} G$ stipulates that a defaulting shareholder may be expelled from the company if he fails to pay the amount called for after having been given a period of grace. According to paragraph 65(1) $A k t G$, each predecessor of the expelled shareholder is liable to the company for the nonpayment of the amount in default, to thee extent that it cannot be obtained from his successors. According to paragraph 65(3) $A k t G$ if the company is unable to obtain satisfaction, it may sell the shares through a stockbroker, and if they are not quoted, by means of a public auction.

\section{THE INCREASE OF CAPITAL}

The above operation requires a shareholders' resolution altering the articles, and subscription for the shares. Both matters must, according to paragraphs 184 and $188 \mathrm{AktG}$, be notified to the commercial register. Unless the articles specify otherwise, the resolution requires a majority consisting of at least three quarters of the capital represented at the meeting. If non-voting preference shares are to be issued, the requisite majority may only be increased. If more than one class of shares exist, class voting is compulsory (para 182(2) $A k t G$ ). If a company has no par value shares it follows from paragraph 182(1) no4 $A k t G$ that the number of such shares shall increase in the same proportion as the share capital. Paragraphs 182(4) $A k t G$ provides that the share capital shall not be increased whilst contributions to share capital are still outstanding and collectible.

Contributions in kind on the occasion of a capital increase are subject to the requirements of paragraph 183(1) $A k t G$, and it follows from paragraph 183(3) $A k t G$ that they have to be audited. Shareholders are granted preemptive rights to subscribe for new shares by paragraph 186(1) $A k t G$, which gives them a period of two weeks after the publication of the issue price in which to exercise such rights. Such pre-emptive rights can be excluded wholly or partially excluded in the resolution on the share capital increase. The resolution requires to be passed by a majority of not less than three quarters of the share capital represented at its passing. The provisions governing the exclusion of such pre-emptive rights are contained in paragraph 186(3) $A k t G$, which also provides that the articles may provide for a higher capital majority and additional requirements. Paragraph 186(3) further provides that pre-emptive rights may be excluded if a capital increase in return for cash contributions does not exceed ten per cent of the share capital, and the issue prices is not materially below the stock exchange price.

The total or partial exclusion of pre-emptive rights must be justified in a written report by the management, in accordance with paragraph 186(4) $A k t G$.

Convertible and warrant bonds, which are bonds that provide their holders with a conversion right or share warrants, and dividend bonds, in which the rights of the 
holders are related to the dividends paid to shareholders, may, according to paragraph $221 A k t G$, be issued on the basis of a resolution of the shareholders' meeting. This will require a majority consisting of not less than three quarters of the share capital represented at the meeting, but the articles may provide for a different majority and additional requirements. According to paragraph 221(4) AktG, shareholders have pre-emptive rights in respect of convertible and warrant bonds, and dividend bonds. By paragraph 188(1) $A k t G$, the completion of the share capital increase has to be reported by the management board and the chairman of the supervisory board for registration in the commercial register. The increase in the share capital becomes effective, according to paragraph $189 \mathrm{Akt} G$, when the completion of the share capital increase is entered in the register.

\section{CONTINGENT INCREASES OF CAPITAL}

The above type of operation is dealt with in considerable detail in paragraphs 192-202 AktG. It follows from paragraphs 192(1) and (2) $A k t G$ that such increases of capital are permissible with respect to the grant of conversion rights or share warrants to the holders of convertible bonds or warrant bonds. They are sometimes used when a merger between companies is being prepared, and also in connection with profit sharing schemes for the benefit of employees and managers of the company or a connected one. The conditional capital may not be more than one half of the share capital: in the case of share options plans for the benefit of employees and managers, the relevant amount is reduced to ten per cent of the share capital, in accordance with paragraph 192(3) AktG. According to paragraph $193 \mathrm{Akt} G$ the relevant increase of capital requires the affirmative votes of the holders of three quarters of the share capital present at the meeting. A higher majority and additional requirements may be provided for in the articles. The Public Companies Act 1965 (as amended) contains detailed rules concerning such matters as contributions in kind (paragraph $194 \mathrm{Akt} G$, paragraph $201 A k t G$ ). The latter provision requires the management board to report, within one month after the expiry of each business year as to the extent to which new shards have been issued in the previous fiscal year.

\section{AUTHORISED CAPITAL (GENEHMIGTES KAPITAL)}

According to paragraphs 202(1) and (3) $A k t G$, the articles may authorise the management board for a maximum period of five years after registration of the company, to increase the original capital up to a specific amount not exceeding one half of the share capital as from the date of such registration. In addition, by paragraph 202(2) $A k t G$, such authorisation may also be given by amendment of the articles, for a period not exceeding five years from the date of the registration of the amendment. The necessary resolution of the shareholders' meeting requires a majority of not less than three quarters of the share capital represented at the meeting. However, the articles may provide for a higher capital majority and contain further requirements. If there is more than one class of shareholder, the consent of each class of shareholder to the resolution is necessary.

The par value of the authorised capital may not, according to paragraph 202(3) $A k t G$, exceed one half of the share capital at the time of such authorisation. Paragraphs 203-206 AktG contain further provisions governing authorised capital.

\section{THE CONVERSION OF RETAINED EARNINGS INTO CAPITAL}

According to paragraph 207(1) AktG, the shareholders' meeting may resolve to increase the share capital by converting the capital reserve or profits reserve into share capital. The shareholders will have new shares alloted to them in proportion to their holdings. However, it follows from paragraph 207(2) $A k t G$ that, if they have no par value shares, and the resolution governing the capital increase contains a suitable provision, such shareholders may simply benefit from the increase in the share capital of the company without any new shares being issued to them.

If any shares are not claimed within one year of the publication of the notice to take delivery of the shares, which is provided for by paragraph 214(1) $A k t G$, and are not subsequently collected despite the giving of the intimation that they may be sold on three occasions in the company's journals, it follows from paragraph 214(3) that the company may sell them on the stock exchange if they are quoted, and if they are not, by public auction, for the benefit of the persons entitled to the shares.

\section{ORDINARY REDUCTIONS OF CAPITAL}

As is also the case with the German private company (Gesellschaft mit berschränker Haftung) a distinction is made in German law between ordinary and simplified (vereinfachte) reductions of capital as far as public companies are concerned. It is also possible to reduce the capital of a public company by means of the mandatory redemption (amortisation) of its shares, if such a measure is prescribed or permitted by the original articles, or an amendment thereof. The latter measure is provided for by paragraphs 237-239 AktG. Ordinary capital reductions are governed by paragraphs 222-228 $A k t G$, and simplified ones by paragraphs 229-236 AktG.

An ordinary reduction of capital requires the adoption of a resolution by a majority of not less than three fourths of the share capital represented at the meeting, according to paragraph 222(1) $A k t G$. The latter provision also stipulates that the articles may make provision for a higher capital majority and contain additional requirements. According to paragraph 222(2) if more than one class of voting shares exists, the ordinary reduction will need a 
separate resolution of each class of shareholders to be effective. If the company has par value shares, the ordinary reduction of capital will require a reduction in such par value. If the result of such a reduction is that the par value attributable to each share will not reach one euro, then according to paragraph 222(4) $A k t G$, the reduction must take place by means of the consolidation of shares. The resolution must stipulate how the reduction is to be made.

An ordinary reduction of share capital becomes effective upon the registration of a resolution in the commercial register (paragraph $224 A k t G$ ). The request for such registration has, according to paragraph $223 \mathrm{Akt} G$, to be made by the management board and the chairman of the supervisory board.

Creditors whose claims came into existence before the registration of the resolution are entitled to demand security within six months of the reduction (paragraph 225(1) AktG. Paragraph 225(2) AktG provides that no distribution to shareholders may occur until the six months period has elapsed, and the requests for security in respect of creditors' claims have been satisfied.

\section{SIMPLIFIED REDUCTION OF CAPITAL}

Paragraph $229 A k t G$ contains general provisions governing a simplified reduction of capital. It follows from paragraph 229(1) $A k t G$ that a simplified reduction of capital may only take place for the purpose of compensating for a decline in the value of assets, setting off other losses, or transferring amounts to the capital reserve. The resolution is required to stipulate that it is made for one of these purposes. Paragraph 229(2) AktG makes it clear that before a simplified reduction can take place. All available reserves must have been used to cover losses. As simplified procedure may not be employed whilst any profit carried forward is shown.

Paragraph $230 \mathrm{Akt} G$ provides that the amounts which are obtained by means of the release of the capital and profits reserves and the capital reduction may not be used to make payments to shareholders. According to paragraph 231 $A k t G$, released funds may only be transferred to legal and capital reserves if the sum of these reserves does not exceed 10 per cent of the share capital. Paragraph 233(2) $A k t G$ provides that after the capital reduction has taken place, dividends exceeding 4 per cent may not be paid for a fiscal year beginning earlier than two years after the resolution for the capital reduction has been adopted, unless creditors have been secured.
A simplified capital reduction may have a retroactive effect. According to paragraph 234(1) $A k t G$, in the annual financial statements for the last fiscal year ending prior to the adoption of the resolution on the capital reduction, the subscribed capital and the legal reserves may be shown as the respective amounts which will prevail after the capital reduction is completed.

Simplified reductions of capital may be resolved on at the same time as a capital increase. If this occurs the capital increase may, according to paragraph $235 A k t G$, be treated in the company's financial statements as having been completed, provided that certain requirements are fulfilled. These are that the new shares have been subscribed for, no contributions in kind have been stipulated, and the legal rules concerning payments set out in paragraph 188(2) $A k t G$ have been complied with. Furthermore, paragraph 235(2) $A k t G$ provides that all resolutions shall be null and void if those on the capital reduction and increase, and on the completion of the increase have not been registered in the commercial register until three months of their adoption.

\section{REDUCTION BY CANCELLATION OF SHARES}

According to paragraph 237(1) $A k t G$, shares may be cancelled by means of mandatory redemption or acquisition by the company. The mandatory redemption of shares may only take place if it is prescribed or permitted in the original articles, or in an amendment thereof. The provisions regarding an ordinary share capital reduction are stated in paragraph 237(2) $A k t G$ to govern such cancellation. However, paragraph 237(3) indicates that they need not be observed if the shares have been fully paid and are surrendered to the company or are cancelled by a charge to distribute profits or another profits reserve, insofar as a charge against such items may be made for this purpose. In the latter case, a resolution of the shareholders' meeting is required. However, paragraph 237(6) $A k t G$ provides that if a mandatory redemption is required by the articles, a resolution of the shareholders' meeting is not required. In such an event the latter requirement is replaced by the need for a decision of the management board requiring cancellation.

Dr Frank Wooldridge 